Journal of Education and Educational Development

8(1), 160-179, 2021

DOI: http://dx.doi.org/10.22555/joeed.v8i1.383

\title{
Effect of Reconstruction Activities on English Writing Skills Mechanical Accuracy I (punctuations) and Mechanical Accuracy II (spellings)
}

\author{
Abdul Rauf \\ University of the Punjab, Pakistan \\ Muhammad Saeed \\ University of the Punjab, Pakistan
}

\begin{abstract}
The present study was conducted to find out the effect of reconstruction activities on grade XI students' English writing skills which included mechanical accuracy I (punctuations) and mechanical accuracy II (spellings). The study was carried out employing a pre-test post-test experimental control group design. A government degree college for boys from district Lahore was selected conveniently for intervention. Sixty students of grade XI were randomized into two equal groups. Students of the experimental group were taught for sixteen weeks continuously. Students' English writing skills were measured through a supply-type English writing skills test. Data were analyzed through paired and independent samples t-tests. Results revealed that reconstruction activities had a statistically significant effect on students' English writing skills. English teachers of grade XI are recommended to practice reconstruction activities for teaching and developing students' English writing skills (punctuations and spellings). Students are recommended to experience reconstruction activities to develop their English writing skills: Punctuations and spellings.
\end{abstract}

Keywords: mechanical accuracy, punctuation, reconstruction activities, spellings, writing skills.

\section{Introduction}

Language is a distinguishing feature of human beings who communicate 
with the help of language. Language is the combination of four skills - listening, speaking, reading, and writing (Omar, 2019). Writing is a productive skill used for communication (Pae, 2019). Writing is the combination of different skills like cohesion, coherence, correct use of grammar, proper selection and use of vocabulary, punctuating the text properly, and use of correct spellings (Ortega, 2013). Proper use of writing skills makes writing comprehensive for the reader. The reader gets the essence of the written text when mechanical accuracies have been used properly (Hyland \& Hyland, 2019). Durukan (2011) has stated that mechanical accuracies are the proper use of punctuations and spellings in writing. The competency of proper punctuation of a text and writing correct spellings of words enable a person to communicate effectively.

Pakistani people learn English as a foreign language (Islam, 2019). Foreign language is taught with the help of different activities because it is learned instead of acquired (Fareed et al., 2016). These activities may facilitate teachers and learners to learn a foreign language and have an easy understanding of the written text. The activities have an exclusive function to engage the reader with text while reading it. These may facilitate readers to get the semantic essence of a text. This semantic understanding of text enables readers to write correctly.

The students at this level are expected to have improved and effective writing skills. This is because writing skills help them to write answers properly in their examination, write daily reports on their study, and do researches (Al-Mukdad, 2019).

Writing is made effective with the help of many other skills. Among them, two are mechanical accuracy I and mechanical accuracy II (Koda, 2005). Mechanical accuracies I and II are known as punctuation and spellings respectively (Neumann et al., 2019). Both punctuations and spellings as writing skills are important to convey ideas through writing effectively (Du Preez \& Fossey, 2012). Punctuations convey true expressions of the writer whereas spellings are to write words in their correct syllables (Al-Mukdad, 2019). Readers can read words in their correct pronunciations and can get semantic assistance to perceive the text (Vo, 2019).

Dexterity in writing skills enables a writer to convey thoughts and ideas in a well-organized way. Writing dexterity can be made possible for learners when they 
pass through the process of intensive reading (Pae, 2019). When a reader engages with text, he/she perceives its sentence structure and word organization. Various activities have been suggested by various linguists to engage the reader with the texts (Lee \& Schallert, 2016; Xu et al., 2019). Thipatdee (2019) has suggested reconstruction activities for reading a text. These activities have also been supported by Lunzer and Gardner (1981) as language teaching activities in their book titled 'Effective use of Reading'. Authors claim that these activities engage readers to read the text critically. During reconstruction activities, the text is presented or given in a jumbled or disordered form to the readers. The readers are then required to rearrange the disordered text in its suitable/original order (Wang \& Shen, 2019). These activities encourage readers to rearrange and bring the text in its original form (Hashmi et al., 2019).

English teachers in Pakistan strive to find out activities that may help them to teach English writing skills effectively. Hence, it was imperative to conduct a study to have scientific evidence for the selection and use of activities that may be found effective for teaching English writing. The current research was conducted to find out the effectiveness of reconstruction activities for teaching and learning English writing skills punctuations and spellings.

\section{Literature Review}

English writing skill plays an important role in the educational career of a learner. It is writing that enables a student to convey his concepts and ideas in exams properly and get good grades/marks. Grade XI students are to write extensive answers in the subject of English. Extensive writing needs accuracy in the use of mechanical accuracies I (punctuations) and II (spellings) to make their writing effective (Manan, 2019). There are various methods to learn mechanical accuracies of English writing skills. Fareed et al., (2016) have suggested intensive and extensive reading for learning mechanical accuracies (punctuations and spellings). Students are preferred to learn English writing skills so that they may perform well in a higher level of education. Proper use of punctuations and correct spellings help to convey their ideas properly in English writing. As English is being taught as a foreign language in Pakistan, students need to learn it with the help of learning grammar and practicing some effective activities. Foreign language learning takes place through direct instruction of grammar and rules of a language (DeKeyser, 2018). 
Learning a language is not age-specific. It may happen at any stage of life. Adult and grown age person can also learn a language (Haukås et al., 2018). Language learners should have competency and knowledge of basic grammar and other related rules of reading and writing a text (Thohir, 2017). A deductive approach is adopted for learning intonations, phonology, morphology, and syntax of the targeted language (Rubio, 2021). Foreign language learning starts happening when a child starts formal schooling. Language skills such as reading and writing are not intuitive. They are learned by learning the signs and symbols known as letters which represent sounds (Gopang et al., 2017). The combinations of such sounds form syllables, syllables become words, words are transferred into phrases, and by combining phrases clauses are formed, and a combination of clauses becomes sentences and the sentences are grouped on one theme which is known as a paragraph. Every word should be written in its proper place in a sentence to convey the proper meaning. Every word has its function like subject, verb, object, adverb, etc. The position of words in a sentence is perceived to construct a meaningful sentence (Ahmad \& Arif, 2020).

The use of punctuation is half language. Punctuation helps the writer to convey the expressions and emotions in writing. It also helps the reader to have true pauses and intonations while reading a text. It is punctuation that guides readers to have pauses and starts at proper places. Another important role of punctuation is of a friend who helps the writer to write clearly for readers (Yusuf et al., 2019). Improper use of punctuation marks creates difficulty for readers to understand what the writer wants to convey. It is punctuation that changes the meanings of a written sentence. Every punctuation mark has its value in written language (Niño, \& Páez, 2018). See how the use of punctuation marks changes the meanings of a sentence. A girl, without her mother, is nothing. A girl: without her, the mother is nothing. Both the sentences are giving opposite meanings due to changing the punctuation marks despite the words are the same in these sentences (Huang, 2019).

Another important writing skill is the use of correct spellings. The English language is composed of alphabets that range from $A$ to $Z$. These alphabets when are joined together form syllables. Syllables are defined as part of words pronounced with a single heartbeat push. In another way, the part of a word pronounced in a single sound is known as a syllable (Huang, 2019). Syllables form a word. Word may be a mono syllable or multi-syllable. For example, cut is a monosyllable word 
whereas beautiful is a multi-syllable word. Learning spellings is very important to write the correct syllables of a word. The word with correct spellings coveys exact meaning and readers get accurate meaning and understanding of the written text (Newton et al., 2018).

Different kinds of activities have been recommended and proposed by linguistics for teaching spellings. Some of them enable a learner to become a creative writer. In some activities, a teacher gives text, not in an original form where students are asked to arrange the text in its original form or sequence. This practice may enable them to have a proper understanding of the punctuations and spellings used in the text. It will give them a sense of the true structure and form of words also (McKay, 2018). Students should be asked to write words by hand. Composing does not encourage them to memorize spellings. Handwriting is an active process of writing where the writer cares for correct spellings. Students memorize the correct spellings of words which they write with hand (Huang, 2019).

Newton et al. (2018) stated that teachers should encourage students to read texts extensively. Reading a text helps them to learn the true pattern and formation of words and sentences. Extensive reading also helps to develop writing skills. So, writing is linked with reading. Another strategy suggested by Yusuf et al., (2019) is the loud pronunciation of words with correct spelling. Phonemic exercise helps students to learn and write words with correct spellings. Anderson (2019) has suggested teachers write difficult and confusing words on board or display them with cards so that students may memorize them easily. Such words should be displayed on board in the class so that these words may be looked at again and again by the learners. It may help them to learn the true spellings of such confusing words (Graham et al., 2018).

Spelling skill helps to write in English effectively. It also makes the future bright for students as they enter into practical life. They develop and write their resume and application effectively for employment in any institution (Durukan, 2011). A resume containing many spelling errors leaves a bad impression and the institution head may not call the candidate for an interview or hire him for a job predicting poor quality of work by such a candidate. Misspelled words may create confusion for a reader while reading a text (Du Preez, \& Fossey, 2012). Readers do not show any interest in reading a text having spelling errors (Lodhi et al., 2019). 
Learning spellings is quite significant for the development of writing skills. A phrase of early school learning I still remember 'when -ING comes to stay, little e runes away!' was to learn spellings of words.

Voracious readers may not be good writers but most of the good writers are serious readers (Ortega, 2013). It is suggested by linguistics that extensive and intensive reading is more effective than grammar and rules learning for the development of effective writing skills. Extensive and intensive reading habits will improve writing skills (Du Preez, \& Fossey, 2012). The reading process involves two important things: Semantic understanding and memorization of the written text (vocabulary) (Schoonen, 2019). Reading also improves the vocabulary of a reader. Vocabulary makes writing effective. Reading enables readers to understand the meanings of words in context (Manan, 2019). Writing skill requires concentration which is not possible without practice. Reading is a source of developing concentration. Hours spending on reading texts improve the ability to concentrate (Hashmi et al., 2019). There are various styles of writing which are learned from reading. Either it is professional writing or writing for personal communication; that style becomes the identity of the writer.

English writing skill plays a significant role in daily as well as professional life. Grade XI students' effective writing skill is a predictor for their good grades in their final examination. The selection of suitable activities which engage students to read a text critically and intensively helps them to comprehend and memorize the text. It may also improve their vocabulary. It is self-evident that beginners do not carry grammar books in their bags rather they carry dictionaries. Vocabulary is an important for effective writing skills also. Punctuation makes writing clear and comprehensive for readers. Spellings help the readers to read words correctly and understand the true and exact meanings of the written text. The current study was conducted to determine the effectiveness of reconstruction activities for the development of students' English writing skills. Writing skills selected for the study were punctuation which was termed as mechanical accuracy one and spelling known as mechanically accuracy two. These two writing skills are important for writing a text correctly and effectively. Many students who learn English as a foreign language write text with errors of punctuations and spellings. Researchers' experience also supported this fact and helped to select the dependent variables for this study. 


\section{Theoretical Framework}

Language learning is a cognitive phenomenon (Ortega, 2013). There is an innate ability to learn the language. This concept has been supported by various cognitive learning theories (Koda, 2005). Cognitive theorists consider language learning is a conscious process that involves thinking and reasoning. Bloom (1956) presented six levels of cognitive domains. These are helpful for language learning. In the first stage, foreign language learners display their ability to recall information and the English language teacher asks questions that can be answered easily with yes and no options. The second stage is to compare and contrast by splitting thoughts into parts and categories to have a deep understanding of the text. The third stage is to have intellectual pursuits of different topics by giving judgments, opinions, and justifying the solution of the problem.

Chomsky (1986) presented the concept of universal grammar for language learning. According to Chomsky (1986), every human being is born with an innate ability of language learning. This innate ability is named as Language Acquisition Device LAD. Piaget's cognitive theory guides language learners stage by stage. Four stages are a true picture of language acquisition. Krashen (1998) postulated five key hypotheses of language acquisition. They also elaborate on the nature of language as the cognitive process of learning.

Language acquisition is a cognitive phenomenon; therefore, the present study comes under the phenomenon of cognitive theories of language learning. Ortega (2013) has supported the idea that writing skill is a cognitive activity that should be carried out under the guidance of cognitive theories.

\section{Conceptual Framework}

The main objective of this study was to find out the effectiveness of reconstruction activities for teaching English writing skills. Two English writing skills were selected for this study. The first was punctuation and the second was spelling. Reconstruction activities were the independent variable of this study and English writing skills were the dependent variable. Figure 1 gives a complete framework of the study by showing independent and dependent variables. 


\section{Figure 1}

\section{Conceptual Framework}

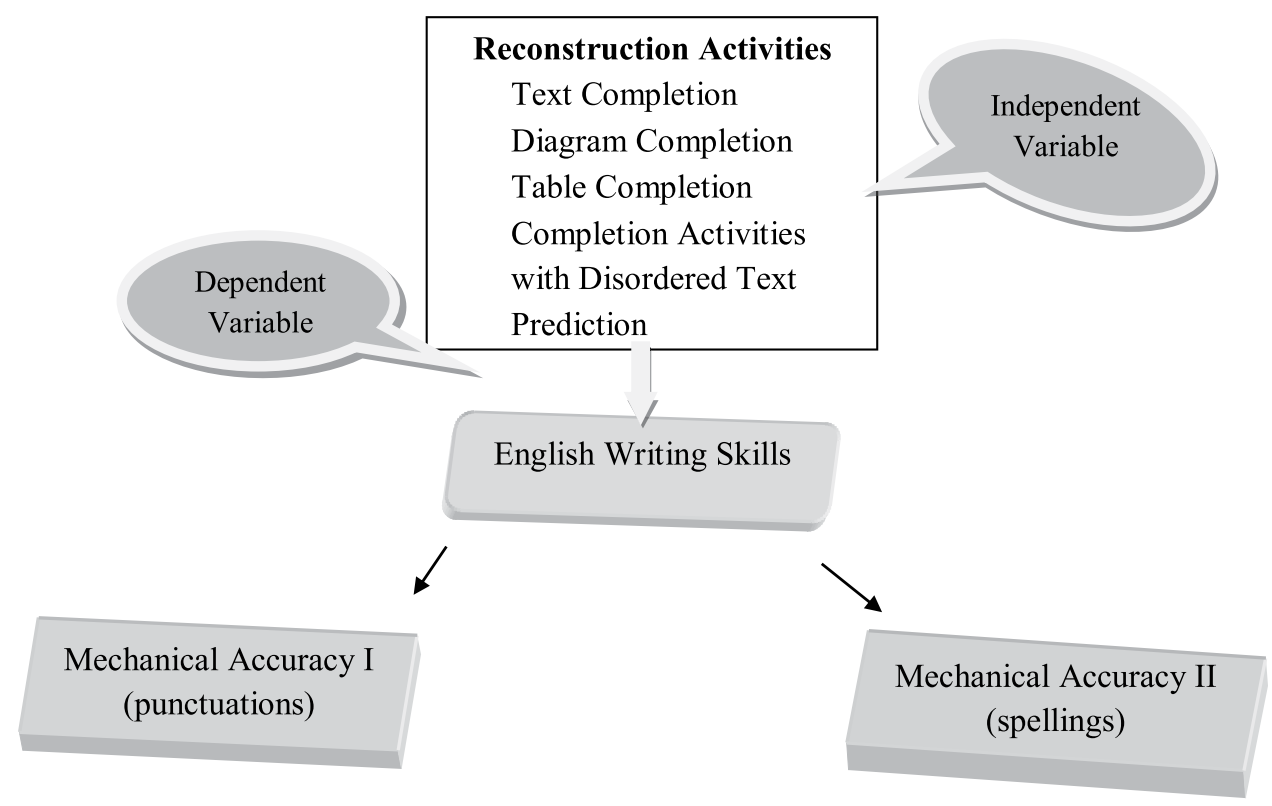

\section{Hypotheses of the Study}

The current study was conducted to test the following null hypotheses:

$\mathrm{H}_{\mathrm{o}} 1$ :There is no statistically significant mean scores difference between experimental and control groups on English writing skill mechanical accuracy I (punctuations).

$\mathrm{H}_{\mathrm{o}} 2$ : There is no statistically significant mean score difference between experimental and control groups on English writing skill mechanical accuracy II (spellings).

\section{Methodology}

\section{Research Design}

Researchers selected a public sector boys' degree college from district Lahore as a cluster to select a sample of the study. Sixty grade XI students were selected randomly out of four hundred (400) total enrolled students with the help of a table of random numbers. These 60 students selected as a sample were divided into two equal groups randomly. One group was selected as experimental and the second 
as a control group. The experimental group was taught 16 weeks continuously. Reconstruction activities were selected for teaching English content from English textbook-I, III, and grammar composition. These books were published by Punjab Curriculum and Textbook Board for the year 2018-19.

\section{Sample}

The independent variable of the study was reconstruction activities. These activities included: a) text completion (cloze) in which broken text is presented to the students, b) diagram completion where the diagram is labeled, c) table completion where a table is filled up by writing relevant and required text, d) completion activities with disordered text where students are required to put disordered text in a proper and logical sequence, and e) prediction where students write what comes next. In these activities, the original text is presented in disordered form, and students are required to reconstruct it in the correct form. This practice develops students' ability to reconstruct ideas and text.

\section{Instrument}

Data were collected through a self-developed supply type English writing skill test having 14 questions. The test was validated by the four experts. Two of them had expertise in educational research and English language teaching (ELT). Two were practicing teachers who were teaching English as a language subject at grade XI-XIV. English Writing Skill Test (EWST) was also piloted and its reliability was 0.75 . Test of English for Educational Purposes (TEEP) was taken as a rubric to mark the solved test. A developed test was given before and after the intervention to collect data for this study.

\section{Data Analysis}

Data for this study were analyzed by applying two main statistics as paired sample t-test and independent samples t-test. Paired sample t-test was applied to compare the pre-test and post-test scores of the same groups to find out the difference. Independent samples t-test was used to find out the difference of variance between the two independent groups: control and experimental. The variance was taken from their pre-test and post-test scores on English as foreign language writing skills punctuations and spellings. 


\section{Findings}

This section provides the detail of data analysis, description, and its interpretation. Data analysis has been presented in the sequence of the hypotheses. Two tests of statistics were applied to test each hypothesis. Paired sample t-test was used to compare the mean score of pre-test and post-test marks of the same group. The Independent sample t-test was to compare both independent groups and find out the variance of their pre-test and post-test scores. The mean score difference was taken out from both groups' pre-test and post-test scores on English writing skills punctuations and spellings. Cohen's d value was taken to find out the effect size of the intervention of reconstruction activities on students' English writing skills punctuations and spellings. The detail of data analysis and its presentation is as under.

\section{Hypothesis 1}

$\mathrm{H}_{\mathrm{o}}$ : There is no statistically significant mean score difference between experimental and control groups on English writing skill mechanical accuracy I (punctuations).

\section{Table 1}

Repeated Measures Paired Sample t-test Results for English Writing Skill Mechanical Accuracy I termed as (punctuations)

\begin{tabular}{lllcccc}
\hline Group & Tests & Mean & SD & t & df & Sig.(two-tailed) \\
\hline \multirow{2}{*}{ Experiment } & Post-test & 36.33 & 1.516 & 16.690 & 29 & .000 \\
& Pre-test & 29.43 & 1.331 & & & \\
\multirow{2}{*}{ Control } & Post-test & 29.93 & 1.388 & 2.065 & 29 & .048 \\
& Pre-test & 29.27 & 1.337 & & & \\
\hline
\end{tabular}

Note: Sig. two tailed $=0.05, n=30$

Table 1 reflects results based on statistical analysis for English writing skill termed as mechanical accuracy one (punctuations). Table 1 statistics revealed that the group received experiment showed enhanced performance in post-test scores as (mean=36.33, $\mathrm{SD}=1.516)$ and the scores in the pre-test were as (mean=29.43, $\mathrm{SD}=1.331$ ). Paired sample t-test statistics show a statistically positive significant effect of reconstruction activities on English writing skill punctuation conditioned as $\mathrm{t}(29)=16.690, \mathrm{p}<0.001$.

On the other hand, the second pair in table 1 yields statistical results for 
the group that was controlled during the study and was taught with the help of traditional methodologies. The results revealed that this group could not perform well in the post-test (mean $=29.93, \mathrm{SD}=1.388$ ) than its cores in the pre-test (mean $=29.27, \mathrm{SD}=1.337$ ). Paired sample t-test results yield that the achievement of the control group in the post-test was statistically insignificant. It is interpreted as the insignificant effect of traditional teaching methodologies on students' English writing skill punctuations conditioned as $\mathrm{t}(29)=2.065, \mathrm{p}>0.001$. This minor development in post-test scores is inferred as a chance in the study rather than the effect of traditional methods of teaching adopted for teaching during the intervention period for the control group.

The results given in table 1 failed to support the stated null hypothesis of the study that $\mathrm{H}_{\mathrm{o}}$ : 'There is no statistically significant mean score difference between experimental and control groups on English writing skill mechanical accuracy I (punctuation)' and research hypothesis is stated as $\mathrm{H}_{1}$ : 'There is statistically significant mean score difference between experimental and control groups on English writing skill mechanical accuracy I (punctuations)'.

\section{Table 2}

Independent Sample t-test Results for Two Independent Groups on English Writing Skill Mechanical Accuracy I (punctuations)

\begin{tabular}{llcccccc}
\hline Test & Groups & Mean & SD & t & df & Sig.(2-tailed) & d \\
\hline Pre - test & Experiment & 29.43 & 1.331 & .484 & 58 & .630 & \\
& Control & 29.27 & 1.337 & & & & \\
Post - test & Experimental & 36.33 & 1.516 & 17.053 & 58 & .000 & .91 \\
& Control & 29.93 & 1.388 & & & & \\
\hline
\end{tabular}

Note: Sig. two tailed $=0.05, \mathrm{n}=30$

Table 2 comprises statistical results taken from statistics of independent sample t-test. Statistical mean comparison of control and experimental groups for pre and post-test scores has been given here. It reveals the variance between control and experimental groups on English writing skills termed punctuation. Pre-test scores of both groups show statistically insignificant difference as experimental was $($ mean $=29.43, \mathrm{SD}=1.331)$ and for control group as (means $=29.27, \mathrm{SD}=$ 1.337 ) with conditions as $\mathrm{t}(58)=.484, \mathrm{p}>.001$. This indicates that both groups did 
not show any disparity in pre-test scores on their performance for English writing skill punctuations. So, the variance was statistically equal between these groups.

Table 2 also shows statistics on the post-test comparison of both independent groups. Post-test scores comparison yields statistically positively significant variance between experimental as $($ mean $=36.33, \mathrm{SD}=1.516)$ and control $($ mean $=29.93, \mathrm{SD}$ $=1.388$ ) with conditions; $\mathrm{t}(58)=17.053, \mathrm{p}<.001$. Cohen's d value measure shows effect size $(\mathrm{d}=.91)$ also supports the statistically significant variance of difference in post-test scores. It reflects that there is a statistically significant difference between the control and experimental groups' means scores of post-test achievement. It was because of the intervention of reconstruction activities for the teaching of English text. The given statistical results could not support the null hypothesis of the study $\mathrm{H}_{\mathrm{o}}$ 'There is no statistically significant mean score difference between experimental and control groups on English writing skill mechanical accuracy I (punctuation)' and an alternate hypothesis is stated as $\mathrm{H}_{1}$ : 'There is statistically significant mean score difference between experimental and control groups on English writing skill mechanical accuracy I (punctuation)'.

The purpose of the study was to find out the effectiveness of reconstruction activities for teaching English writing skills punctuations and spellings. Statistical results gained from data analysis yielded the effectiveness of reconstruction activities for teaching English writing skill mechanical accuracy I (punctuations). Table 1 showed statistically significant improved performance of the experimental group on post-test scores due to teaching English text through reconstruction activities, whereas the control group showed statistically insignificant improvement in post-test scores because this group was taught English text without the help of reconstruction activities.

Statistical analysis also revealed that both independent groups were not different in variance in pre-test scores. However, both groups had a statistically positive significant variance in post-test mean scores. The experimental group outperformed in post-test scores and practical significance yielded a high effect size of the independent variable (reconstruction activities) on the dependent variable (mechanical accuracy I (punctuation)). Based on the above findings, the conclusion is stated that reconstruction activities are effective for teaching and developing mechanical accuracy I (punctuations) as an English writing skill. 


\section{Hypothesis 2}

$\mathrm{H}_{\mathrm{o}}$ : There is no statistically significant mean score difference between experimental and control groups on English writing skill mechanical accuracy II (spellings).

\section{Table 3}

Repeated Measures Paired Sample t-test Mean Score Comparison of Experimental and Control Groups on English Writing Skill Mechanical Accuracy II (spellings)

\begin{tabular}{llccccc}
\hline Group & Tests & Mean & SD & t & df & Sig. (two-tailed) \\
\hline Experiment & Post-test & 36.67 & 1.807 & 20.161 & 29 & .000 \\
& Pre-test & 29.13 & 1.358 & & & \\
\multirow{2}{*}{ Control } & Post-test & 30.03 & 1.520 & 1.869 & 29 & .072 \\
& Pre-test & 29.30 & 1.368 & & & \\
\hline
\end{tabular}

Note: Sig. two tailed $=0.05, \mathrm{n}=30$

Statistical results obtained from paired sample t-test have been given in table 3 for English writing skill spellings. Post-test scores of the experimental group in table 3 are better (mean $=36.67, \mathrm{SD}=1.807$ ) than the scores of pre-test as (mean $=29.13$, SD 1.358). These statistical values gained from paired sample t-test reflect that this difference is statistically significant for English writing skill spellings with a condition of $\mathrm{t}(29)=20.161, \mathrm{p}<0.001$. It is concluded that this is the effect of reconstruction activities intervention on students' English writing skills performance.

Statistical values in table 3 and pair two are results for the control group. These values reflect statistically insignificant improved scores of the control group in post-assessment as (mean $=30.03, \mathrm{SD}=1.520)$ than the scores of pre-assessment as (mean=29.30, $\mathrm{SD}=1.368$ ). It shows that traditional methodologies as lecture method, grammar-translation method, textbook reading method, used for teaching English text had no statistically significant effect on control group performance for English writing skill spellings as condition $\mathrm{t}(29)=1.869, \mathrm{p}>0.001$. This insignificant difference between the performance of pre and post-test scores of the control group is interpreted as by chance.

Statistical values and analysis given in table 3 could not support the stated null hypothesis for the study as $\mathrm{H}_{\mathrm{o}}$ : 'There is no statistically significant mean 
score difference between experimental and control groups on English writing skill mechanical accuracy II (spelling)' and a research hypothesis is stated as $\mathrm{H}_{1}$ : 'There is statistically significant mean score difference between experimental and control groups on English writing skill mechanical accuracy II (spelling)'.

\section{Table 4}

Independent Sample t-test Mean Score Comparison of Independent Groups on English Writing Skill Mechanical Accuracy II (spellings)

\begin{tabular}{llcccccc}
\hline Tests & Groups & Mean & SD & t & df & Sig.(two-tailed) & d \\
\hline Pre-test & Experiment & 29.13 & 1.358 & -.474 & 58 & .638 & \\
& Control & 29.30 & 1.368 & & & & \\
Post-test & Experiment & 36.67 & 1.807 & 15.390 & 58 & .000 & .89 \\
& Control & 30.03 & 1.520 & & & &
\end{tabular}

Note: Sig. two tailed $=0.05, \mathrm{n}=30$

Table 4 comprises the independent sample t-test statistical values for the comparison between experimental and control groups for pre and post-test scores. This statistical comparison is on the scores for English writing skill spellings. Pre-test scores analysis shows that both groups are equal in performance of preintervention assessment as experimental group was (mean $=29.13, \mathrm{SD}=1.358$ ) and the control group was (means $=29.30, \mathrm{SD}=1.368$ ) with conditions $\mathrm{t}(58)=$ $-.474, p>.001$. There is equality of both groups in pre-test performance. So, there is no statistically significant difference between control and experimental group performance on English writing skill spellings.

Post-test statistical results in table 4 are gained from independent sample statistics for control and experimental groups. Results show that both groups were statistically significantly different in their post-test scores. The group received intervention was $($ mean $=36.67, \mathrm{SD}=1.807)$ and the control group $($ mean $=30.03$, $\mathrm{SD}=1.520$ ) with conditions $\mathrm{t}(58)=15.390, \mathrm{p}<.001$. There is a statistically positively significant difference in post-test scores of both groups. Cohen's effect size value $(d=.89)$ supports the statistically significant effect of reconstruction activities on students English writing skill spellings. It is concluded that traditional teaching methods as a grammar-translation method, lecture method, and textbook reading had a statistically insignificant effect on English writing skill spellings. So, the 
sampled data and results failed to support the stated null hypothesis for the study as $\mathrm{H}_{\mathrm{o}}$ 'There is no statistically significant mean score difference between experimental and control groups on English writing skill mechanical accuracy II (spelling)' and a research hypothesis is stated as $\mathrm{H}_{1}$ : 'There is statistically significant mean score difference between experimental and control groups on English writing skill mechanical accuracy II (spelling)'.

Data analysis reflected the effectiveness of reconstruction activities for teaching and developing English writing skills termed mechanical accuracy II (spellings). Table 3 showed outperformance of the experimental group in post-test assessment scores. The Control group, however, could not yield outperformance in the post-test assessment on English writing skill mechanical accuracy II (spellings). Cohen's d value showed a high effect size of the independent variable (reconstruction activities) on the dependent variable (mechanical accuracy II (spellings). The conclusion is stated that reconstruction activities are statistically effective for teaching and developing English writing skills termed mechanical accuracy II (spellings).

\section{Discussion}

The present study results showed that reconstruction activities are statistically significant for the development and teaching of grade XI students' English writing skills. Students of the experimental group show improved performance on English writing skill punctuation. These findings are consistent with Islam (2019). These findings are also consistent with Wang and Shen (2019) and Thipatdee (2019). Effect size .91 showed a high positive effect of reconstruction activities on punctuations learning as an English writing skill. Pae (2019) presents a solution for learning punctuation at the secondary and higher secondary level by suggesting activities for teaching English as a foreign language. Neumann et al., (2019) suggest that teacher-made activities would develop students' English writing skills.

The current study also revealed that students of the experimental group outperformed in post-test scores on English writing skill spellings. These findings are consistent with Al-Mukdad (2019), Omar (2019), and Manan (2019). The practical significance of these findings .89 also reflected a high positive significant effect of reconstruction activities on learning spellings as English writing skill. Lodhi et al., (2019) suggested interactive activities for teaching English writing 
skills. Anderson (2019) claimed that English writing skills can be developed with the help of different activities used for teaching a foreign language.

The present study results are summarized that reconstruction activities are effective for the development of both English writing skills: Mechanical accuracies punctuations and spellings at grade XI. Teaching English as foreign language writing skills in Pakistan can be made effective by teaching with the help of reconstruction activities. Reconstruction activities engage readers with text to read carefully and go beyond the literal understanding of the text. This intensive reading helps the reader to perform well in writing. They commit little mistakes in punctuation and spellings while writing in English.

Reconstruction activities were claimed by Lunzer and Gardner (1981) to have the nature to engage readers with texts for intensive reading of the text. The current study as an experimental study was carried out to observe the effect of reconstruction activities as classroom activities on grade XI students' English writing skills punctuations and spellings termed as mechanical accuracies. This study was conducted through a control group experimental design with pre and post-test observations.

\section{Conclusion and Recommendations}

The present study results are concluded that reconstruction activities are effective for the development and teaching of English writing skill mechanical accuracy I (punctuations). The group receives intervention of reconstruction activities shows statistically improved achievement scores in post-test assessment. This improved performance in post-test observation is due to the intervention of reconstruction activities for teaching English text. English is being taught as a foreign language in Pakistan. Foreign language teaching is a complex task. It can be made easy by adopting different activities which may assist teachers and students to teach and learn English as a language effectively. Every skill of a language requires different nature of activities for their development. So, reconstruction activities are considered effective for the development of English writing skill punctuations.

Results expose that students have improved performance in post-test scores on English writing skill mechanical accuracy II (spellings). Based on students' outperformance, the conclusion of the study is stated that reconstruction activities 
are effective to teach English writing skills mechanical accuracy II (spellings). Learning spellings in the English language requires intensive reading. Intensive reading helps the reader to have a close understanding of word formation. Word formation includes letters and syllables and the relation of syllables with other syllables. While reading a text, students learn the true pattern of spellings used for word-formation. It also helps them to perceive the true formation of syllabi of the words. Ultimately students learn appropriate spellings of a word.

Based on the findings of the present study, researchers recommend English teachers who are teaching English as a foreign language at grade XI to use or practice reconstruction activities as classroom activities for teaching English writing skill mechanical accuracy I (punctuations). They are further recommended to practice reconstruction activities for the development of English writing skill mechanical accuracy II (spellings).

Grade XI students are also recommended for the use of reconstruction activities to read English text to develop their English writing skills punctuation known as mechanical accuracy I. They are further recommended to experience reconstruction activities to develop their English writing skill mechanical accuracy II (spellings).

\section{References}

Ahmad, I., \& Arif, M. S. (2020). Teachers' perception of English language teaching at tertiary level education in Pakistan. Pakistan Social Science Review, 4(1), 191203.

Al-Mukdad, S. (2019). Investigating English academic writing problems encountered by Arab International University students. Theory and Practice in Language Studies, 9(3), 300-306.

Anderson, N. J. (2019). Integration with other language skills. The TESOL Encyclopedia of English Language Teaching, 23(2), 1-7.

Bloom, B. S. (1956). Taxonomy of educational objectives: The classification of educational objectives. Handbook I: The cognitive domain. David McKay Co., Inc.

Chomsky, N. (1986). Knowledge of language: Its nature, origin, and use. Preager Publisher. https://books.google.com/s?hl=en\&lr=\&id=b0VZPtZDL8kC\&oi=fnd\&pg=PR11 $\&$ dq $=$ Chomsky+(1986)\&ots=kdmh4BS93a\&sig=3kvsQE2zWLT2NwP1HfB6Z4u ZfIg 
DeKeyser, R. M. (2018). Age in learning and teaching grammar. The TESOL Encyclopedia of English Language Teaching, 1-6.

Du Preez, I., \& Fossey, A. (2012). Developing academic writing skills as part of graduate attributes in undergraduate curricula. South African Journal of Higher Education, 26(2), 346-357.

Durukan, E. (2011). Effects of cooperative integrated reading and composition (CIRC) technique on reading-writing skills. Educational Research and Reviews, 6(1), 102109.

Fareed, M., Ashraf, A., \& Bilal, M. (2016). ESL learners' writing skills: Problems, factors and suggestions. Journal of Education and Social Sciences, 4(2), 81-92.

Gopang, I. B., Ansari, S., Kulsoom, U., \& Laghari, A. (2017). An empirical investigation of foreign language anxiety in Pakistani university. International Journal of English Linguistics, 7(2), 21-35.

Graham, S., Liu, X., Bartlett, B., Ng, C., Harris, K. R., Aitken, A., \& Talukdar, J. (2018).

Reading for writing: A meta-analysis of the impact of reading interventions on writing. Review of Educational Research, 88(2), 243-284.

Hashmi, M. A., Mahmood, M. I., \& Naz, T. (2019). Impact of mass media in the use of English slangwords/short forms among Pakistani students. Int J EduSci, 24(13), 8-12.

Haukås, Å., Bjørke, C., \& Dypedahl, M. (2018). Metacognition in language learning and teaching. Taylor \& Francis.

Huang, D. (2019). The potential of sentence trees in English grammar teaching. English Language Teaching, 12(3), 178-190.

Hyland, K., \& Hyland, F. (Eds.). (2019). Feedback in second language writing: Contexts and issues. Cambridge University Press.

Islam, M. (2019). Learning experiences and motivation of undergraduate students in Pakistani

EFL classrooms: A qualitative study. Bulletin of Education and Research, 41(1), 221-235.

Krashen, S. D. (1981). Second language acquisition and second language learning. University of Southern California.

Koda, K. (2005). Insights into second language reading: A cross-linguistic approach. Cambridge University Press.

Lee, J., \& Schallert, D. L. (2016). Exploring the reading-writing connection: A yearlong classroom-based experimental study of middle school students developing literacy in a new language. Reading Research Quarterly, 51(2), 143-164.

Lodhi, M. A., Farman, H., Ullah, I., Gul, A., Tahira, F., \& Saleem, S. (2019). Evaluation 
of English textbook of intermediate class from students' perspectives. English Language Teaching, 12(3), 26-36.

Lunzer, E., \& Gardner, K. (1981). The effective use of reading. https://eric.ed.gov/?id=ED174979

Manan, S. A. (2019). Myth of English teaching and learning: A study of practices in the low-cost schools in Pakistan. Asian Englishes, 21(2), 172-189.

McKay, S. L. (2018). English as an international language: What it is and what it means for pedagogy. RELC Journal, 49(1), 9-23.

Neumann, H., Padden, N., \& McDonough, K. (2019). Beyond English language proficiency scores: Understanding the academic performance of international undergraduate students during the first year of study. Higher Education Research \& Development, 38(2), 324-338.

Newton, J., Ferris, D., Goh, C., Grabe, W., Stoller, F., \& Vandergrift, L. (2018). Teaching English to second language learners in academic contexts. Routledge.

Niño, F. L., \& Páez, M. E. V. (2018). Building writing skills in English in fifth graders: Analysis of strategies based on literature and creativity. English Language Teaching, 11(9), 102-117.

Omar, Y. Z. (2019). Teaching pedagogical grammar in context to enrich English language learners' academic writing. Online Submission, 2(3), 213-225.

Ortega, L. (2013). Understanding second language acquisition. Routledge.

Pae, T. I. (2019). A simultaneous analysis of relations between L1 and L2 skills in reading and writing. Reading Research Quarterly, 54(1), 109-124.

Rubio, F. (Ed.). (2021). Self-esteem and foreign language learning. Cambridge Scholars Publishing.

Schoonen, R. (2019). Are reading and writing building on the same skills? The relationship between reading and writing in L1 and EFL. Reading and Writing, 32(3), 511-535.

Thipatdee, G. (2019). The development of English writing skills through techniques of sentence skeleton and signpost word analysis for English major students. English Language Teaching, 12(4), 32-38.

Thohir, L. (2017). Motivation in a foreign language teaching and learning. Vision: Journal for Language and Foreign Language Learning, 6(1), 20-29. Vo, S. (2019). Use of lexical features in non-native academic writing. Journal of Second Language Writing, 44(2), 1-12.

Wang, W., \& Shen, L. (2019). Chinese MBA students' perceptions of business English writing: Needs analysis and student self-reflections. English Language Teaching, 12(5), 20-29. 
Xu, Z., Banerjee, M., Ramirez, G., Zhu, G., \& Wijekumar, K. (2019). The effectiveness of educational technology applications on adult English language learners' writing quality: A meta-analysis. Computer Assisted Language Learning, 32(1-2), 132162.

Yusuf, Q., Jusoh, Z., \& Yusuf, Y. Q. (2019). Cooperative learning strategies to enhance writing skills among second language learners. International Journal of Instruction, 12(1), 1399-1412. 